\title{
PROGRESS IN IMPLEMENTING THE SUSTAINABLE DEVELOPMENT CONCEPT INTO SOCIOECONOMIC DEVELOPMENT IN POLAND COMPARED TO OTHER MEMBER STATES
}

Ewa Mazur-Wierzbicka, Ph.D. Associate Professor

University of Szczecin

Faculty of Economics and Management

Mickiewicza 64, 71-101 Szczecin

e-mail: ewa.mazur-wierzbicka@wp.pl

Received 7 August 2014, Accepted 29 April 2015

\begin{abstract}
Sustainable development-related issues have been discussed in the public discourse worldwide since the 1960's. The socioeconomic development theme is one of the key themes in sustainable development singled out by the European Union with a special attention paid to three crucial areas, namely: economic development, competitiveness, innovation and eco-efficiency as well as employment. Therefore, the aim of this article is to assess the implementation level of the sustainable development concept in the area of socioeconomic development in Poland compared to other Member States. In order to achieve the articles aim the following two research tasks were performed: sustainable development in terms of socioeconomic development in the EU strategic documents has been described and the sustainable development concept in the area of socioeconomic concept in Poland compared to other Member States has been analysed. The analysis showed that the gap between Poland and the 'old' EU has been narrowed since 2004; however, the progress in implementing the sustainable development concept into socioeconomic development was still slow comparing to both the EU-10 and EU-15. This article is based on the available reference, government documents and the analysis was conducted on the basis of secondary data provided by Eurostat.
\end{abstract}

Keywords: sustainable development, socioeconomic development, European Union.

JEL classification: O1, Q56. 


\section{Introduction}

The issues concerning sustainable development have been discussed in public discourse all over the world since the 1960's. Sustainable development plays a crucial role in European Union politics as well. The division of the said issues adopted by the EU (i.e. assigning certain issues to certain themes pursuant to the set of sustainable development indicators) refers directly to the Renewed EU Sustainable Development Strategy. One of the themes referring directly to the socioeconomic issues is theme 1 . Socioeconomic development, which in turn is further divided into three subthemes: economic development, competitiveness, innovation and ecoefficiency as well as employment.

This article puts forward the following hypothesis: the presence of Poland in the EU structure and necessity to comply with all EU requirements resulted in the progressing implementation of the sustainable development concept in the socioeconomic development theme. The aim of this article is to assess the implementation level of the sustainable development concept in the socioeconomic development theme in Poland compared to other Member States.

In order to meet the articles objective two research tasks have been determined:

- to single out socioeconomic development as a sustainable development theme,

- to analyse the progress of implementing the sustainable development concept into socioeconomic development in Poland compared to other Member States.

The time perspective is set from 2004 to 2010, the analysis starts with 2004 due to the fact that Poland joined the European Union in 2004 and finishes with 2010 when implementation of the Lisbon Strategy was completed. Moreover, the reason for choosing such a time perspective is the lack of sufficient data available even for 2011.

The analysis was carried out for two groups of Member States, i.e. the EU-10 (those which joined the European Union on May 1, 2004) and the EU-15 (the so-called old EU).

This article is based on the available reference, government documents and secondary data provided by Eurostat.

\section{Sustainable development in the socio-economic development theme in EU strategic documents}

At the summit in June 2001, the Göteborg European Council complemented the Lisbon Strategy with components of sustainable development where 'A Sustainable Europe for a Better World: A European Union Strategy for Sustainable Development' (European Commission, 2001) was adopted. The strategy integrated economic (economic prosperity), social (social 
equity and cohesion) and environmental (environmental protection) objectives. Therefore, the fact that the economic objectives were singled out confirmed the significance of socioeconomic development for the evolution of the sustainable development concept. Having verified the existing Sustainable Development Strategy, the European Council adopted the Renewed EU Sustainable Development Strategy in June 2006 (European Council, 2006). One of the key objectives became economic prosperity understood as promoting a prosperous, innovative, knowledge-rich, competitive and eco-efficient economy which provides high living standards as well as full and high-quality employment throughout the European Union (European Council, 2006). The present set of sustainable development indicators refers directly to the Renewed Strategy. They have been organized into 10 theme groups reflecting seven key challenges among which socioeconomic development indicators (theme 1) play a crucial role (Table 1).

Table 1. Division of EU sustainable development indicators in the socioeconomic development theme

\begin{tabular}{|c|c|c|c|}
\hline Theme & $\begin{array}{c}\text { Level } 1 \\
\text { - headline indicators }\end{array}$ & $\begin{array}{c}\text { Level } 2 \\
- \text { operational objectives and targets }\end{array}$ & $\begin{array}{c}\text { Level } 3 \\
\text { - explanatory variables }\end{array}$ \\
\hline \multirow{6}{*}{$\begin{array}{l}\text { Socioeconomic } \\
\text { development }\end{array}$} & \multirow{6}{*}{ GDP per capita } & \multicolumn{2}{|c|}{ Economic development } \\
\hline & & Investment by institutional sectors & $\begin{array}{l}\text { Dispersion of regional GDP } \\
\text { per inhabitant (NUTS 3) } \\
\text { Net national income } \\
\text { Household saving rate }\end{array}$ \\
\hline & & \multicolumn{2}{|c|}{ Competitiveness, innovation and eco-efficiency } \\
\hline & & $\begin{array}{l}\text { Real labour productivity growth } \\
\text { per hour worked }\end{array}$ & $\begin{array}{l}\text { Total R\&D expenditure } \\
\text { Turnover from innovation } \\
\text { Real effective exchange rate } \\
\text { Energy intensity of the economy }\end{array}$ \\
\hline & & \multicolumn{2}{|c|}{ Employment } \\
\hline & & Total employment rate & $\begin{array}{l}\text { Employment rate, by sex } \\
\text { Employment rate, by highest level } \\
\quad \text { of education attained } \\
\text { Dispersion of regional employment } \\
\quad \text { rates, by sex } \\
\text { Unemployment rate, by sex } \\
\text { Unemployment rate, by age group }\end{array}$ \\
\hline
\end{tabular}

Source: http://epp.eurostat.ec.europa.eu/portal/page/portal/sdi/indicators/theme1.

Since the Lisbon Strategy was completed, a new strategic EU document 'A Strategy for smart, sustainable and inclusive growth - Europe 2020' ('Europa 2020' strategy) (European Commission, 2010) is being implemented. It identifies five headline targets of which:

- $75 \%$ of the population aged $20-64$ should be employed, 
- $3 \%$ of the EU's GDP should be invested in R\&D

refer directly to theme 1 .

In order to achieve such targets so-called flagship initiatives have been put forward, two of them: 'Innovation Union' and 'An agenda for new skills and jobs' refer directly to theme 1. The remaining flagship initiatives support indirectly reaching the strategy objectives.

As the European Commission recommended, the main objectives of 'Europe 2020' have been translated into national targets and trajectories and they are included in the National Reform Programmes where the implementation methods and necessary resources are determined.

\section{Sustainable development in the socioeconomic development theme - a comparative} analysis

As Europe faces the present changes, particularly those caused by the economic crisis, it seems to be important to analyse the implementation progress of the sustainable development concept in the socioeconomic development theme in Poland compared to two groups of Member States i.e. the EU-10 and EU-15. In order to conduct an in-depth analysis, the indicators from all the three levels have been applied with various levels of detail. ${ }^{1}$ Data availability was the main criterion for selecting variables. It was important to obtain a complete set of data on certain areas for each member state that is why some indicators were not taken into account due to the lack of data for some Member States.

The analysis relates to the first stage of implementing sustainable development, for Poland it was from 2004 to 2010 i.e. from Poland's accession to the European Union until the completion of implementing the Lisbon Strategy.

The basis for determining a mean value of a certain measure among a given group of Member States at a certain time (within the time perspective) was its median. Additionally, in order to make charts more clear, data was transformed from destimulants into stimulants.

The headline indicator in theme 1 is GDP per capita. Within the time perspective, the average GDP growth in Poland was $4.5 \%$ a year and it was high comparing to the EU-25. At the time of the crisis, despite the economic slowdown Poland was one of very few Member States that recorded economic growth. In 2010, GDP dynamics in Poland were significantly above the EU average. Nevertheless, as the data in table 2 show, Poland's GDP was below the median for both the EU-10 and EU-15.

\footnotetext{
${ }^{1}$ Level 1 - the lowest level of detail, level 3 - the highest level of detail.
} 
Table 2. GDP per capita in Poland comparing to the EU-10 and selected descriptive measures for GDP distribution in 2004 and 2010

\begin{tabular}{|l|c|c|c|c|}
\hline \multirow{2}{*}{\multicolumn{2}{|c|}{ Detailed list }} & \multicolumn{2}{|c|}{2004} & \multicolumn{2}{c|}{2010} \\
\cline { 2 - 5 } & $\begin{array}{c}\text { value } \\
\text { (euro) }\end{array}$ & ranking & $\begin{array}{c}\text { value } \\
\text { (euro) }\end{array}$ & ranking \\
\hline Cyprus & 17,300 & 1 & 21,000 & 1 \\
\hline Slovenia & 13,600 & 2 & 17,400 & 2 \\
\hline Malta & 11,300 & 3 & 15,000 & 3 \\
\hline Czech Republic & 9,000 & 4 & 14,300 & 4 \\
\hline Hungary & 8,100 & 5 & 9,700 & 7 \\
\hline Estonia & 7,200 & 6 & 10,700 & 6 \\
\hline Slovakia & 6,300 & 7 & 12,100 & 5 \\
\hline Lithuania & 5,300 & 8 & 8,400 & 9 \\
\hline Poland & 5,300 & 9 & 9,200 & 8 \\
\hline Latvia & 4,800 & 10 & 8,100 & 10 \\
\hline EU-10 median & 7,650 & & 11,400 & \\
\hline EU-15 median & 28,700 & & 32,700 & \\
\hline EU-15 maximum value & 59,900 & Luxembourg & 78,600 & Luxembourg \\
\hline EU-15 minimum value & 14,200 & Portugal & 16,200 & Portugal \\
\hline
\end{tabular}

Source: own compilation.

In 2010, economic development in Poland was quite stable and not vulnerable to unfavourable conditions in the world and European economies. In 2007, GDP growth amounted to $6.8 \%$ being the highest one since Poland's accession to the EU. Such a remarkable result was recorded mainly due to high household consumption and exceptionally high demand for investment.

In order to complete the said picture it is necessary to take level 2 and 3 indicators, describing socioeconomic development, into account.

Net national income was the only indicator taken into account within the sub-theme of economic development. It was higher in Poland comparing to the EU-10 median and in 2010 even to the EU-15 median.

Figure 1 shows the distribution of indicators in the next subtheme 'Competitiveness, innovation and eco-efficiency'.

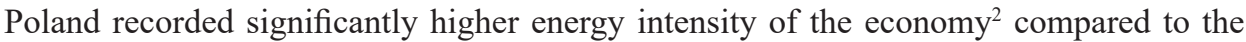
EU-10, EU-15 ${ }^{3}$. A gradual progress in the decreasing energy intensity of the Polish economy

\footnotetext{
2 Energy intensity of the economy is the ratio between the Gross Inland Consumption of Energy and GDP (in fixed prices of 2,000 calculated at 2,000 euro exchange rates). This ratio is the result of dividing the Gross Inland Consumption by the GDP (since Gross Inland Consumption is measured in kgoe (kilogram of oil equivalent) and GDP in 1,000 EUR, this ratio is measured in kgoe per 1,000 EUR). Definition provided by the Central Statistical Office.

${ }^{3}$ Poland - 389,554 kg of oil equivalent per 1,000 euro (kgoe/1,000euro); Finland - 247,802 kgoe/1,000euro (the highest indicator in the EU-15), Ireland - 98,329 kgoe/1,000euro (the lowest indicator in the EU-15).
} 
was recorded from 2004 to 2010 (average decrease by 4\% a year). It was mainly caused by stable energy consumption.

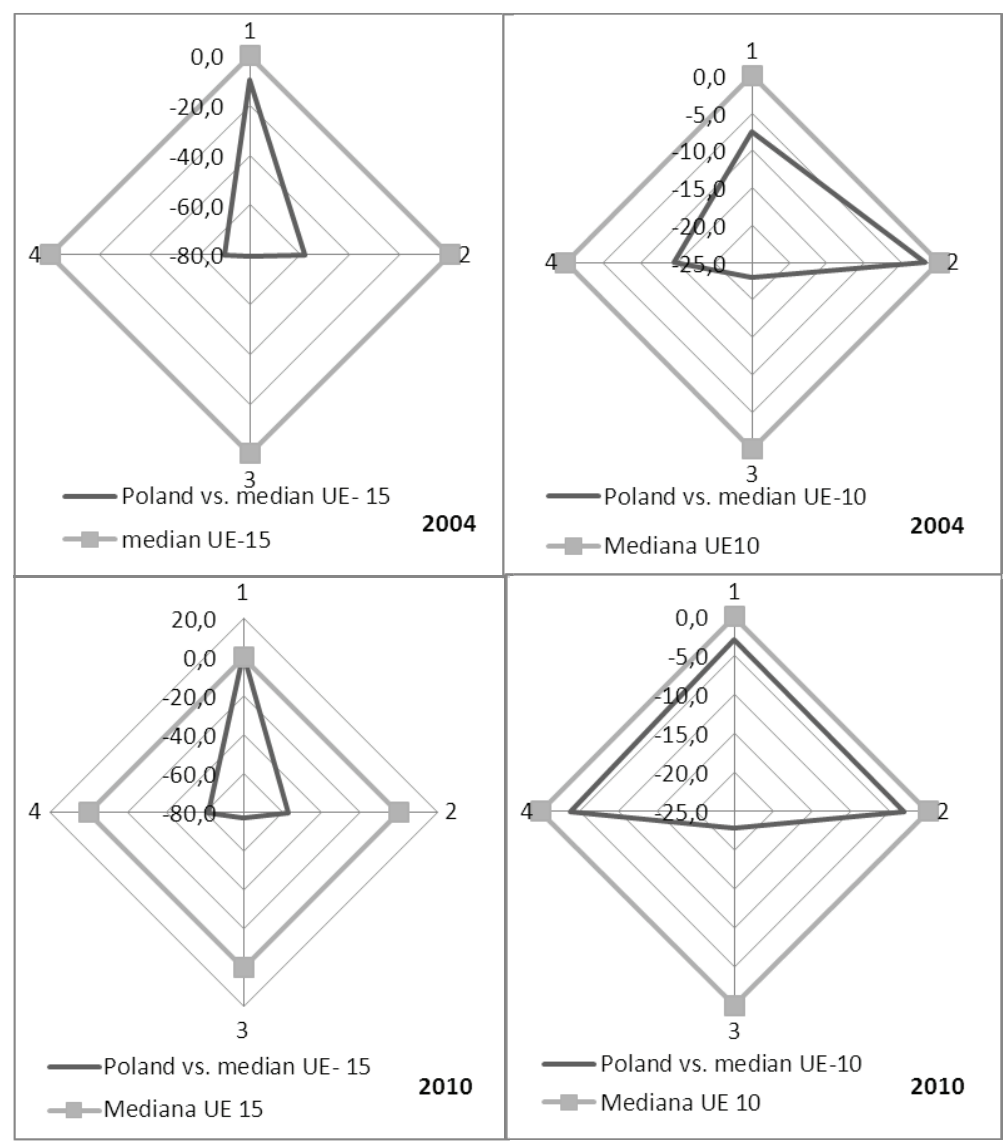

1 - Real effective exchange rate.

2 - Energy intensity of the economy.

3 - Real labour productivity growth per hour worked.

4 - Total R\&D expenditure.

Fig. 1. Sustainable development indicators of 'Competitiveness, innovation and eco-efficiency' in Poland compared to median for the EU-10 and EU-15 in 2004 and 2010

Source: own compilation.

The median of energy intensity of the economy for the EU-10 and EU-15 was decreasing (for the EU-25 at a rate similar to $2 \%$ ). It was in compliance with the sustainable energy policy aimed at striving to maintain a balance between energy security, meeting the social needs of current and future generations, economy competitiveness and environmental protection. 
The driving force for innovation and competitiveness is research and development (R\&D). Poland recorded rather low expenditure in R\&D compared to other Member States. In 2004, it was 3.27 times higher in the European Union than in Poland, in 2010 - 2.72 times (in 2004 Poland was ranked 20th among the EU-25 and 6th among the EU-10 in this regard, in $2010-21$ st and 6th respectively). Such a discrepancy was particularly visible when comparing Poland to Member States with a higher indicator than under discussion: Finland (3.9\%), Sweden (3.39\%) and Denmark (3.07\%). ${ }^{4}$ In 2010 compared to 2004, Poland recorded a slight GDP growth in R\&D expenditure from $(0.56 \%)$ to $(0.74 \%)$. Despite the increase in the indicator for Poland in both 2004 and 2010, it was still lower than the EU-10 and EU-15 medians - Figure 1. For most of the time, the share of R\&D expenditure in the European Union's GDP was quite stable (although it varied among Member States).

In 2004, the increase in labour productivity was observed in Member States. The highest labour productivity was recorded in Luxembourg, when the EU-10 is concerned in Cyprus. In Poland, the said indicator was one of the lowest in the EU-10 and consequently in the EU-25. As Figure 1 shows, its value is significantly below the EU-10 and EU-25 medians at that time. However, it should be noticed that Poland was recording a growth in labour productivity year after year (in 2010, the highest value was 9.5\%). For comparison purposes, Portugal recorded the lowest labour productivity in the old EU; it was $16.4 \%$ in 2010.

In the EU-10, particularly in Central and Eastern Europe, the higher pace of growth in labour productivity was observed comparing to the EU-15; it was mainly a consequence of "catching up" in terms of economy and development after the accession of the new Member States. The growth in labour productivity slowed down in the aftermath of the economic crisis similarly to other indicators of sustainable development.

As to a real effective exchange rate, it should be noticed that both in 2004 and 2010 its value in Poland was lower than the EU-10 medians. Compared to the EU-15 medians in 2004, Poland's median was slightly higher; unfortunately in 2010 it was lower.

Another subtheme concerns employment. It includes both employment and unemployment rates. As data included in figure 2 shows Poland's employment rates both in 2004 and 2010 were lower than the EU-10 and EU-25 medians.

\footnotetext{
${ }_{4}$ These three Member States recorded 3\% of GDP invested in R\&D as determined in 'Europe 2020'.
} 


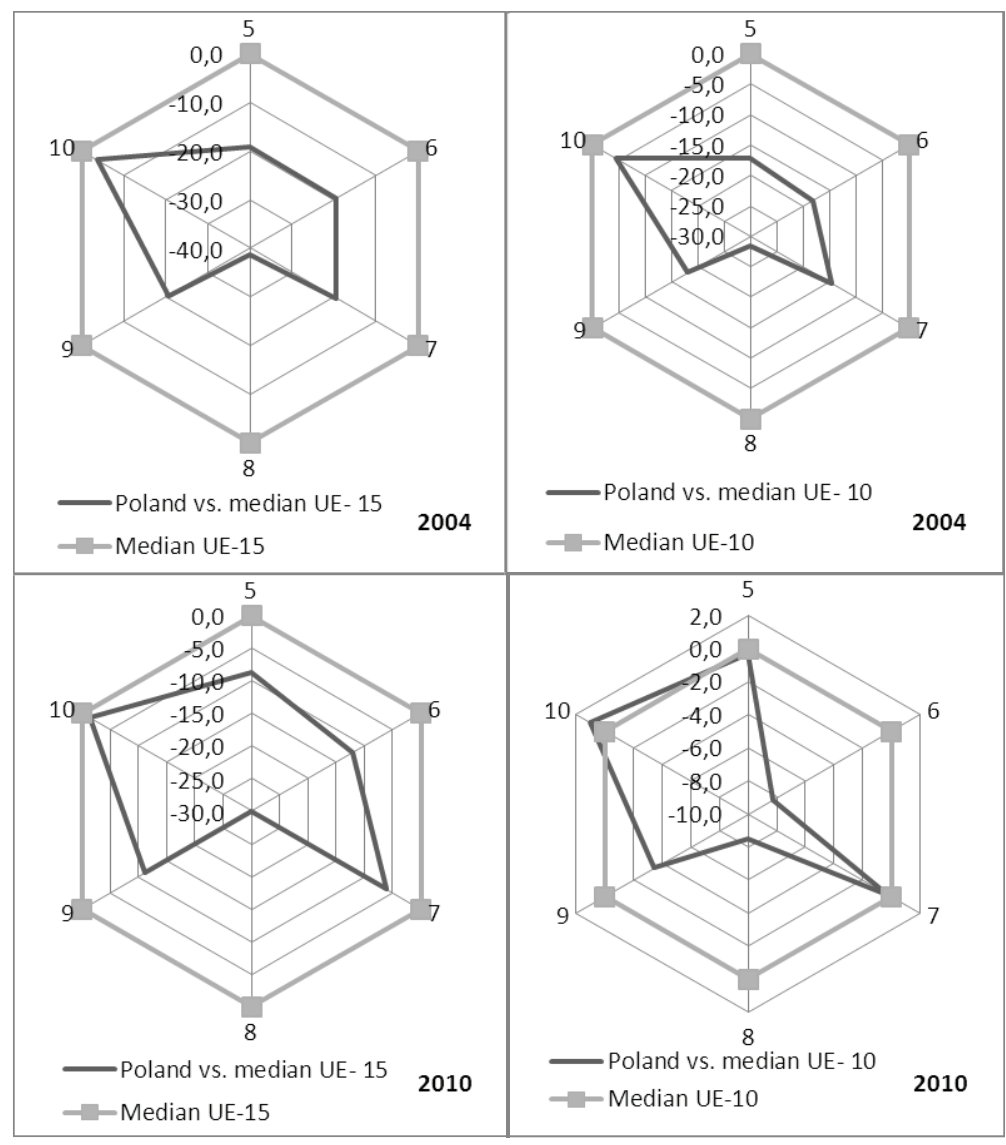

\footnotetext{
5 - Total employment rate.

6 - Employment rate, by sex - women.

7 - Employment rate, by sex - men.

8 - Employment rate, by highest level of education attained (0-2).

9 - Employment rate, by highest level of education attained (3-4).

10 - Employment rate, by highest level of education attained (5-6).
}

Fig. 2. Employment indicators in Poland compared to the EU-10 and EU-15 medians in 2004 and 2010.

Source: own compilation.

The changes in the employment indicator within the said time can be divided into two stages: from 2004 until 2008 when both the EU-10 and EU-15 recorded its growth and after 2008 when the employment rate experienced a downturn which undoubtedly was a consequence of the economic crisis. 
In 2010, Poland recorded one of the lowest total employment ${ }^{5}$ among all reporting Member States (the said indicator was lower in Spain, Lithuania, Slovakia, Italy, Malta and Hungary). The highest employment indicator was recorded in Denmark, the Netherlands and Sweden. In 2010, a slight employment growth was recorded not only in Poland but also in Hungary, Malta, Cyprus (EU-10) and Belgium, Germany, France, Luxembourg, Austria and Sweden (EU-15).

Employment rate at the age group of 50-64 years in Poland was significantly lower in 2010 comparing to the EU-25 and it amounted to $47 \%$, while the mean employment rate in the EU-25 was at 56.7\%. From 2004 to 2010, a certain trend was observed both in the EU-10 (including Poland) and the EU-15: the highest employment rate was recorded among people with tertiary education (ISCED 5-6), ${ }^{6}$ and the lowest one among people with the lowest education (ISCED $0-2$ ). As a result, people who decide to obtain a university degree (which is time and moneyconsuming) want to find a job and gain sufficient income which compensates their effort to obtain a degree (See Becker, 1990). Additionally, the decrease in employees with the lowest education is a consequence of the European economy increasing demand for specialists, and well-educated people.

The analysis of the statistical data shows a large discrepancy between the unemployment rate in the so-called old EU and Member States joining the EU prior to 2004 (except for Malta and Cyprus).

Within the said time, Poland made a significant progress compared to the EU-10; the unemployment rate amounted to $19 \%$ in 2004 , while it accounted for $9.6 \%$ in 2010 . For comparison purposes: Spain $(2004-10.9 \%, 2010$ - 20.1\% the highest unemployment rate across the EU-25), Latvia (2004 - 11.2\%, 2010 - 19.8\% the highest unemployment rate across the EU-10). In 2004, Poland recorded the highest unemployment rate throughout the EU-25, while in 2010 was ranked 15th showing a far better situation in the labour market than Ireland, Greece, Portugal, and France (EU-15).

When analysing unemployment rate by sex, it is visible that in Poland, the unemployment rate for males was lower than that for females (in 2009 the unemployment rate for males amounted to $18.2 \%$ and for females $-20.0 \%$, while in $2010: 9.3 \%, 10.0 \%$ respectively). That trend was typical of most of the UE-10. Some significant discrepancies were found in Spain, Italy, France

\footnotetext{
5 Employment indicator (employment rate) calculated by dividing the number of employed by the total population aged 15 and above. Definition provided by the Central Statistical Office.

${ }^{6}$ Education level by the International Standard Classification of Education (ISCED): level 0-2 pre-primary education, primary education, lower secondary education, level 3-4 secondary and post secondary education, level 5-6 tertiary education.
} 
and Greece (e.g. in 2004: the unemployment rate for males amounted to $6.6 \%$, for females 16.2\%, while in 2010: $9.2 \%$ and 16.2\% respectively). The unemployment rate in Poland for both males and females was above the indicator medians for the UE-10 and EU-15. The data shows that females suffered more from the economic crisis than males. As a result, females became unemployed more often. The reasons behind a higher unemployment rate among women in Poland are the following: the seasonal Polish labour market, entrepreneurs' preferences who believe women are less flexible than men, hiring women in industries vulnerable to economic turbulence or under employment transformation (such as: health care, education) (Council of Ministers 2012). In 2010, some Member States recorded higher unemployment rates for males than for females. It could be caused by a deteriorating economic situation in the industries hiring mostly men (e.g. building, production).

What is striking, the unemployment rate at the age group below 25 was higher compared to the age group of 25-70 years. It also concerns both the EU-10 and EU-15. It was caused mainly by an unfavourable demographic trend in Europe and ageing society, what also meant prolonged working age in most Member States (particularly in the EU-15), as a consequence existing jobs (particularly after 2008 when their number was decreasing) were taken by people already present in the labour market (not by people entering it) so mainly by $25-74$ year old people.

The unemployment rate at the age group of 25-74 years in Poland improved significantly compared to the other EU-10. Without any doubt, an economic boom in four years after Poland's accession to the EU contributed to the said improvement, which in turn, affected creating new jobs supported by the European Funds aimed at stimulating professional activity, improving employment opportunities among young people and those threatened by unemployment. It mainly concerned the European Social Fund which under the Lisbon Strategy was aimed at increasing job opportunities, enhancing geographic and professional mobility across the European Union. The Fund promoted equal opportunities in the labour market (by excluding various forms of discrimination), adapting employees to the changes on-going in the industry, striving for stability and employment growth (Hitiris, 2003). On the other hand, after Poland's accession to the European Union, some people migrated to seek a job in the European labour market. The statistical data shows that at the end of 2010 about 1,990,000 Poles were living temporary outside of Poland..$^{7}$ The vast majority of Polish emigrants, ca. 1,615,000, lived in Member States. About 80-90\% of people who left Poland from May 1, 2004 until the end of 2010 were taking up jobs there or looking for it Central Statistical Office, 2012).

\footnotetext{
7 It was by 120,000 less than in 2009 .
} 


\section{Conclusions}

The analysis of available references, the secondary data allowed achieving the set research tasks and article objective. The hypothesis set in this article was positively verified. The presence of Poland in the EU structure and the necessity to comply with all the EU requirements resulted in the progressing implementation of the sustainable development concept in the socioeconomic development theme.

The analysis carried out in this article allowed drawing the following conclusions.

Firstly, comparing Poland's progress in implementing the sustainable development concept in the area of socioeconomic development in 2010 and 2004, it has to be stated that the said progress was higher which is confirmed by positive trends in most of the said indicators. As a result, individual Poles and Polish businessmen showed initiative and seized the opportunities of a single market (which resulted in decreased unemployment and poverty, within the first three years in particular) and European Funds.

Secondly, most of the said indicators were poorer in Poland compared to other Member States (both in the EU-15 and EU-10).

Thirdly, although the gap between Poland and old EU has been narrowed, it was still large.

Fourthly, Poland has to take a number of steps aimed mainly at increasing Poland's competitiveness, decreasing the energy intensity of the economy, increasing the employment rate as well as decreasing the unemployment rate. The guidelines laid down in the 'Europe 2020' strategy and other related documents are crucial incentives to do so.

\section{References}

Becker, G. (1990). Ekonomiczna teoria zachowań ludzkich. Warsaw: PWN.

Central Statistical Office. (2012). Press conference material of September 25. Warsaw.

Council of Ministers. (2012). 2012-2014 National Action Plan for Employment (KPDZ/20122014). Warsaw.

European Commission. (2001). Communication from the Commission, A Sustainable Europe for a Better World: A European Union Strategy for Sustainable Development, COM (2001)264 final. Brussels, 15.05.2001. 
European Commission. (2010). 'Europe 2020'. A Strategy for smart, sustainable and inclusive development, Communication from the Commission, COM (2010) 2020. Brussels, 3.03.2010.

European Council. (2006). Renewed EU Sustainable Development Strategy. Brussels.

Hitiris, T. (2003). European Union Economics. London: Prentice Hall, Pearson Education.

http://epp.eurostat.ec.europa.eu/portal/page/portal/sdi/indicators/theme1 (10.02.2014). 